\title{
On the New Institutional Economics of Markets ${ }^{1}$
}

\author{
Rudolf Richter
}

The objection essentially is that the theory floats in the air. It is as if one studied the circulation of the blood without having a body. Firms have no substance. Markets exist without laws...(COASE [1984, 230] on neoclassical economics).

\section{Introductory Remarks}

This paper is motivated by the remark of Coase $(1988$, p. 7$)$ that "although economists claim to study the working of the market, in modern economic theory the market itself has an even more shadowy role than the firm."

It seems natural to reflect on Coase's complaint by extending Coase's (1937) argument for the nature of the firm by postulating positive transaction costs also for the nature of the market (as an institution or organization). Let us use the concept of transaction costs in the wider sense of "the costs of running the economic system" (Arrow 1969, 48) that include besides the costs of using the market the costs of using, maintaining, changing etc. of institutions or organizations in general. In addition let us assume they include also the costs of boundedly rational decisionmaking (like the costs of gathering and processing information) and of the consequences of imperfect foresight (like the costs of planning mistakes, backup arrangements, reorganization etc.).

Now, in the neoclassical world of costless transactions, perfect foresight and perfect rationality there is no need for a specific market organization. It does not matter whether an individual trades only occasionally or professionally, whether he goes to the next street corner or sets up a whole

\footnotetext{
${ }^{1}$ Paper prepared as basis of a lecture held at the Faculty of Sociology, Bielefeld University, Bielefeld, Germany, 12 November 2008.
} 
network of trade relationships. This is the world of general equilibrium theory ${ }^{2}$ in which every body is trading with every body else on whatever goods (he wishes) for all times to come. However, the model is institutionally neutral, i.e., the institutional framework is irrelevant if only the optimality conditions of general equilibrium theory are satisfied. Thus, it would apply equally to a socialist as to a capitalist economy ${ }^{3}$ or to "hierarchies and markets." In other words, we cannot differentiate between various institutional arrangements. Institutions don't matter; their productive results are the same as long as the optimality conditions of general equilibrium theory are satisfied.

By contrast, Coase (1937) argued that the assumption of positive transaction costs is critical for discriminating between different institutions, in his case, the firm and the market. Under certain circumstances the institution "firm" is preferred to that of the "market" because "certain marketing costs are saved" (Coase 1937, 392). ${ }^{4}$ The same argument can be used to explain the existence of different specific market organizations such as the London Stock Exchange, eBay, weekly town markets, annual fairs, real estate markets, producers' markets like the US automobile market, etc.. These specific markets can be conceived as privately established and operated public goods with the aim to economize on transaction costs. Their specific norms may be understood as being based on the elementary constitutional rules of the liberal state regarding private property, contractual obligations and obligations from tortuous acts that are guaranteed by a supreme authority: the state. ${ }^{5}$ Some specific markets may evolve spontaneously such as the black market for US cigarettes in Frankfurt (Main), Germany, after World War II, the "Polish

\footnotetext{
${ }^{2}$ Partial equilibrium theory is an artifact of it.

3 “The optimality conditions [of general equilibrium theory], being simply technical requirements, contain no ideological implications. They apply equally to capitalism, socialism, or any other "ism." Whatever the political ideology of a country, it could make all of its citizens better off by ensuring that production and allocation satisfied the optimality conditions. (Lancaster 1969, 276) See also Furubotn and Richter (2005, Section 1.2).

${ }^{4}$ Coase continues: "The entrepreneur has to carry out his function at less cost, taking into account the fact that he may get factors of production at a lower price than the market transactions which he supersedes, because it is always possible to revert to the open market if he fails to do this." (ibid.)

${ }_{5}^{5}$ A simplification, cf. North $(1990,58)$
} 
Market" in Berlin after the collapse of the Berlin Wall in 1989, etc. ${ }^{6}$ Yet most specific markets are established or "made" by identifiable people - such as the members of a city council or the producers of new products - even though they may contain spontaneous elements. ${ }^{7}$

In every case, in the world of positive transaction costs, actors who plan to buy or sell a specific (type of) good face two (interrelated) problems of institutional choice: First, to choose or establish a specific market organization ${ }^{8}$ within which to trade the good - such as a stock exchange, a weekly market, a producers' market, an online market, etc. and, second, to choose within that market organization a specific exchange contract (a contractual governance structure $^{9}$ ) with their trading partner. Both are nonmarket coordination problems - the first is a problem of the coordination of individual plans between a multiplicity of suppliers and demanders; the second is a problem of the coordination of individual plans between two parties: a supplier and a demander. Both aim at an institution or organization that economizes most on transaction costs (minimizes transaction costs). The Coasian question, which we set out to deal with, relates to the first coordination problem: the establishment or choice of the least transaction cost organization of specific markets on which traders wish to do business. ${ }^{10}$ The second organization problem, the choice of the transaction cost economizing governance structure of exchange contracts, is the problem of Williamson's transaction cost economics.

\footnotetext{
${ }^{6}$ On the rise of open-air markets all over Eastern Europe in the 1990s see SIK AND WALLACE (1999); KARAZMANMORAWETZ AND PILGRAM (1993) (quoted from EGBERT 2007).

7 "Spontaneous" and "made" order in the sense of Hayek (1973) Law, Legislation and Liberty, Vol. I, Rules and Order, Ch. 2).

${ }^{8}$ Or market "order" (HAYEK 1973, 40 ff.).

${ }^{9}$ WilliamsON (1985, 32): "Organize transactions so as to economize on bounded rationality while simultaneously safeguarding the against the hazards of opportunism." --- Since large numbers of contracts are incomplete, the parties to a contract must agree, either explicitly or tacitly, "about the procedure [the 'constitution'] that will be employed to deal with problems that may arise in the future" (Macneil 1974, 753).

${ }^{10}$ A private collective good would be a club good in the case of a closed market, or a private public good in case of an open market - similar to COASE's (1974) lighthouse example.
} 
Note that neoclassical economists (among them anti trust economists) would answer the Coasian question by referring to the zero transaction ideal of perfect market as a model for market design. They assume that the organization or institution of perfect markets would lead the parties costless to Pareto-efficient general market equilibrium. Deviations of real world markets from the ideal of perfect markets would result in undesirable Pareto-inferior equilibria. By contrast, neoinstitutionalist economists discard comparisons between the ideal norm of perfect markets and an existing "imperfect" institutional arrangement, a comparison Demsetz (1969) ${ }^{11}$ criticized as “nirvana approach". Instead neoinstitutional economists apply what Demsetz calls a "comparative institution approach in which the relevant choice is between alternative real institutional arrangements." 12 Variables are now not only prices and quantities (measured in real numbers) but also complex institutional arrangements such as the New York Stock Exchange, eBay, the US automobile market, the New York real estate market etc. Though, Coase compares only two general types of institutional arrangements, markets and firms, he could have gone on to compare with each other various specific types (organizational templates) of firms or markets or hybrid forms between markets and firms. In the NIE world of positive transaction costs, the existing divers organizational templates distinguish themselves, i. a., by their level of transaction costs measured, say, per unit of output or turnover. Coase reasons for the nature of the firm (1937) could be extended to the nature of the existing different specific organizational templates of markets and firms that can be seen as resulting from the difference in their average transaction cost levels.

\footnotetext{
${ }^{11}$ Demsetz, H. (1969), ,Information and Efficiency: Another Viewpoint“", Journal of Law and Economics, 12, 1 22.

${ }^{12}$ To say that markets are inefficient because of transaction costs and other disturbances of real life "...is to say little more than that the competitive equilibrium would be different if these were not the facts of life. But, if they are the facts of life...then truly efficient institutions will yield different long-run equilibrium conditions than those now used to describe the ideal norm." (Demsetz 1969, 19).
} 
In a sense, Coase (1937) argument for the nature of the firm can be interpreted as the result of a neoclassical optimization task, viz., to choose an institution arrangement that minimizes transaction costs given certain constraints.

To exemplify formally: Assume an unbounded set of presently known least cost organizational templates of markets $\{\mathrm{T}\}$ like auctions, brokered markets, producers' markets, etc. In analogy to the cost function of the theory of the firm, assume - somewhat heroically - the existence of a smooth, twice differentiable market transaction cost function $\kappa$. Transaction costs $\kappa$ depend on the market turnover level $\omega$ (as analogy to the firm's output level) and the specific organizational template $\mathrm{T}$ of the market

$$
\kappa=\kappa(T, \omega), \kappa_{\omega}>0 .
$$

In words: We assume transaction costs $\kappa$ are an increasing function of the market's turnover level $\omega$ given a specific organizational template T (in analogy to the firm's production function $\Phi$ ).

Understanding the Coasian question as a problem of optimizing under constraints, we ask for a market organization $\mathrm{T}$ that minimizes transaction costs for an aspired turnover level $\omega^{*}$; that is

$$
\operatorname{Min}_{\mathrm{T}} \kappa(\mathrm{T}, \omega) \text {, subject to } \omega=\omega^{*} .
$$

Following Selten $(1990,657)$, this is clearly no boundedly rational choice. Anyhow, how does a collective of anonymous buyers and sellers choose a transaction cost minimizing market organization - and where from are the "presently known organizational templates"?

Classical economists since David Hume (at the latest) answer the problem of optimal collective choice plus specific designs of the organizational templates by some "invisible hand mechanism" (as a result of "spontaneous" evolution - as Hayek would say. New institutional economists avoid a clear answer. The concept of transaction costs, the decisive variable of their target function, remains vague. To allow for bounded rationality and incomplete foresight it would be better to use instead of above wide concept of transaction costs three separate target variables: transaction costs (in the narrow sense of the costs of using the market), bounded rationality and imperfect foresight. We would then have a three-valued target function ${ }^{13}$ to be economized in a boundedly

\footnotetext{
${ }^{13}$ Sort of a vector maximization problem.
} 
rational sense, i.e., by using instead of an optimization under constraints approach ${ }^{14}$ a heuristic decision strategy (like comparing several known market organizations to decide, from which to start from).

In addition, real life markets are more than a mix of formal and informal systems of social norms. Personal relationships matter: Markets are weaved into networks of personal relationships between actors whose economic effect is important, but difficult to measure and hard to transfer.

Exchange networks are both, difficult to build and hard to demolish. To destroy them by plain force (war or revolution) takes more than only ten or fifteen years - as is illustrated by the German Wirtschaftswunder of $1948 \mathrm{ff}$. in comparison with the slow adaptation of the East German economy to the West German situation after German reunification of $1990 .^{15}$

\section{The Design of Market Organizations}

The organization of "perfect markets" is fully described by the abstract elementary constitutional norms of private property, contractual obligations and liabilities from tort. ${ }^{16}$ Instead, in the more realistic world of the NIE, market organizations need to include also some more concrete orders (agreements) as aid of trade such as common timing, ${ }^{17}$ common units of measurement, ${ }^{18}$ common locations of trade (local markets, ${ }^{19}$ an internet platform), common usage of money, the

\footnotetext{
${ }^{14}$ Thus, Selten (1990) strongly opposes the ideas of the "constrained optimization" school and argues that "there is no reason to suppose that human behavior is guided by a few abstract principles" (1990, 653). Experimental work tends to support his view (e.g., Kahneman 1994).

${ }^{15}$ As for the German Wirtschaftswunder, much of the pre 1933 global personal and business connections still existed or were easily revived in 1948. Big West German corporations like Mercedes, Siemens, Bosch, Leitz etc - and West German small and medium-sized firms and their networks of national and international contacts still existed. On the other hand, East Germany had lost all of its old firms and business contacts by 1990. It had to start virtually from scratch.

${ }^{16}$ The proper design of "market order," i.e., the order of perfect markets, is the central issue of German Ordnungspolitik as advocated by Walter Eucken, Franz Böhm, Wilhelm Röpke, Alexander Rüstow and the "Austrian" economist Friedrich August von Hayek; see SCHMIDTCHEN (1984).

${ }^{17}$ The calendar introduced by Pope Gregor XIII in 1582 that was only slowly accepted by all trading nation states; the introduction of international time zones based on Greenwich Time was suggested by an international congress 1889. It took a couple of decennia until it was accepted globally.

${ }^{18}$ The extension of local markets required an extension of the range of validity of units of measurement and weight. The metric system has been introduced in the $19^{\text {th }}$ century and is by now almost globally applied. The only exceptions among large states are England and USA. Germany introduced the metric system in 1868.

${ }^{19}$ Local markets are extended to large area markets ("nationwide" or "global" markets).
} 
institutional construct of "liquidity," 20 the organization of price formation (auctioning, rigid prices cum advertising, wage bargaining between unions and employers associations) - and all this interlinked by a network of social ties between traders and the rest of the economy. Markets do not function in a social vacuum. ${ }^{21}$

However, the centuries old debate on the nature and evolution of money illustrates the scientific and political difficulties that such aids of trade (and trust into them) can raise. ${ }^{22}$

Interestingly, the assumed use of money in markets (which presupposes frictions $=$ transaction costs) did not induce economists to call such markets "imperfect markets." For the same reason, financial markets are seen as a natural part of perfect markets (= efficient markets) though they make only sense if - due to imperfect foresight - pure futures markets "fail" (Hicks 1946, p. ?). To adapt freely Goethe: Two souls alas! are dwelling in the neoclassical economist's breast.

As for location issues only transportation costs, not the more general concept of transaction costs, have been considered and gave rise to a special branch of neoclassical economics: location theory. ${ }^{23}$

Location theory is neglected by new institutional economists in spite of the fact that, up to date, transportation costs make up a non-negligible part of the costs of using the market ("transaction costs"). The problem is that the transportation problem lends itself to standard "quantitative" analysis (optimization under constraints), while institutional economics requires very different, "qualitative," methods of optimization. Still, location problems are a central issue of market organization and should not be disregarded completely by institutional economists.

As for the role of social relationships, one sociological textbook example comes from Abolafia (1984) who showed that even in security exchanges - the classic example of perfect markets social structure (informal organization) matters; it helps improving the market mechanism.

\footnotetext{
${ }^{20}$ The ability to fulfill one's payment obligations. (Stïtzel 1959, 625).

${ }^{21}$ HAMILTON AND FEENSTRA $(1995,61)$.

${ }^{22}$ On the history of monetary economics see Dimand (2008).

${ }^{23}$ More or less started by THÜNEN (1826).
} 
"Fiercely independent economic actors are, at the same time, reliant on one another." (Abolafia $1984,132)$

There exists no systematic theory of the NIE of markets, only a number of considerations on specific issues concerning the basic functions of trade, i.e., the activities of search, inspection, contracting, execution, control, and enforcement. We content ourselves to describe and comment on some prominent examples from the NIE literature and related approaches to illustrate the kind of considerations that are at least part of an evolving new institutional economic theory of markets.

For clarity we are reducing above six elementary transaction activities into the following three categories:

1. Precontractual activities (search and inspection)

2. Contracting (contract formation)

3. Postcontractual activities (execution, control and enforcement).

After a compressed report and comments on some of the institutional economic answers on above issues we shall indicate some possible steps towards a more systematic presentation of the characteristics of the NIE of markets.

\section{Precontractual activities: Search and Inspection}

A typical "classical" answer to the problem of search and inspection would be to do what textbooks do, ${ }^{24}$ namely, to allow only for spot trade and let buyers and sellers meet at the same time and same place, such as on weekly markets. But even then information about product prices

\footnotetext{
${ }^{24}$ Cf. Stackelberg (1948, 219 ff.).
} 
and product quality ${ }^{25}$ will be a problem under NIE conditions. As for product quality, Nelson (1970) points out that information about it cannot be achieved by way of search as well as through experience. "Experience will be used when search becomes too expensive" (318). Nelson correspondingly distinguishes between "search goods" and "experience goods." Typical $\underline{\text { search }}$ goods are, according to his classification, cameras, furniture, china, glassware. Typical

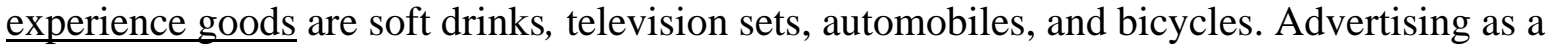
vehicle for information plays a role in the case of search goods, but personal inspection is also important. Misleading advertising results in costs to the advertiser, for "he suffers a decline in his credibility for future advertisements and pays the costs of processing non-buying customers" (Nelson 1974, 730). Therefore, "consumers can have some confidence that the advertising of search qualities bears a close relation to the truth" (730). This is much less so in case of experience goods: "The major control that consumers have over the market for experience qualities is whether they repeat the purchase of a brand or not" (730). Therefore, consumers cannot expect much direct information from advertising concerning experience qualities. What they get is important indirect information: "The consumer can learn that the brand advertises." Nelson contents that this is the useful information. Advertisements for experience goods need not have informational content. Their total informational role .... is simply contained in their existence" (732). It is advertisement for experience goods that is of particular interest to

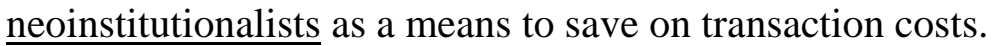

A general answer to Nelson's problem is to view advertising expenditures (sunk cost) as hostages in the hands of ones customers. The analytical background for that view is provided by the theory of self-enforcing contracts, which we'll return to further below.

\footnotetext{
25 Nelson assumes that consumers already know where they can obtain each of the options open to them. Their information problem is to evaluate the utility of each option. He defines search to include any way of evaluating these options subject to two restrictions: (1) the consumer must inspect the option, and (2) the inspection must occur prior to purchasing the brand $(1970,312)$.
} 
A different way to cut search cost is to use personal ties as done by Granovetter (1974/1995) for cases of job search. According to his sample, personal contact is the predominant method of finding out about jobs. Thus, the relevant factors of finding a job turn out to be social. Job finding behavior is "... heavily embedded in other social processes that closely constrain and determine its course and results." $(1995,39)$. Of those people finding a job through contacts, the majority saw their contact only occasionally or rarely, i.e., was only weakly tied with their contacts. Granovetter is certainly no new institutional economist (in fact he is opposing it - or at least Williamson's TCA). But his study fits well into the style of neoinstitional research. Granovetter himself concedes that many of his findings are easily explained in terms of rational behavior. $(1974 / 1995,96)$ The reason would be that information is costly (loc. cit. 99). But also the quality of information would explain why employers and employees prefer to or make use of personal contacts in securing labor market information.

The point underlined by Granovetter's study is that markets do not function in a social vacuum (Hamilton and Feenstra 1995, 61). Personal contacts, cooperation, social ties between potential buyers and sellers (including hierarchical relationships and relationships arising from organized groups) all play roles. Analytically this aspect is based on network analysis. Actors are, as Granovetter puts it, "embedded" in a network of social relations. They

"... are so constrained by ongoing socials relations that to construe them as independent is a grievous misunderstanding." (Granovetter 1985/1995, 212).

These arguments were put forward not only by Granovetter but also by other sociologists among them Coleman (1984), Burt (1983), Abolafia (1984).

Barzel (1982) concentrates much of his work on the problems and costs of inspection (he calls it "measurement"). To eliminate errors in measurement completely would be too costly. The value of equally priced items on weekly markets, e.g., will differ, and people will spend resources to 
acquire the difference. Such resource expenditure would be wasteful, and Barzel hypothesizes that traders therefore implicitly agree on methods that help to reduce this kind of resource use. The customer's random selection from an already optimally sorted commodity will avoid the excessive expense. A mutual agreement among traders is to be expected that some readily obtainable information will be suppressed to preempt opportunities for excessive measurement (Barzel 1982, 48).

Analytically, Barzel's measurement problem results from the existence of asymmetric information between buyer and seller - with the seller being in general the better-informed party (Spence 1974). While sellers of low quality products ("lemons") might be tempted to mislead their customers, sellers of high quality products will undertake efforts to "signal" their quality. For a signal to be effective (credible), it must be unprofitable for sellers of low quality products to imitate it (Spence 1976, 592). Thus, e.g., "To offer a warranty is a costly activity for the seller of lemons, but not very costly for the seller of good cars. Hence, this signal allows the buyers to discriminate between the two types of cars" (Varian 1992, 469). Provided it is sufficiently costly, the seller of the high quality product can afford to apply the signal "warrantee," while the seller of low quality products cannot. Similarly, investment in brand-name capital through, for example, high advertising expenditures can be seen as credible signals.

Kenney and Klein (1983) describe the somewhat peculiar selling policy of the Central Selling Organization (CSO) of the De Beers Group ${ }^{26}$ as a practical device to avoid oversearching. They suggest that its selling practice contributes to a reduction of search cost by minimizing buyers' oversearching for information. Stones are sorted according to shape, quality, colour, and weight in more than two thousand categories. Still, the variants in the value of stones within each category are substantial. To avoid oversearching, stones of each category are sorted by De Beers

\footnotetext{
${ }^{26}$ That markets most of the world's gem-quality uncut diamonds.
} 
into imperfectly homogeneous categories and sold in preselected blocks to preselected buyers at non-negotiable prices. In this case the agreement among marketers is somewhat forced by the (once) monopolistic seller: If buyers' rejected the sales offer they were no more invited by De Beers to purchase stones. However, this policy has (or had) also its advantages to buyers, who, since they have a long-term business relationship with De Beers, are earning rents the present value of which is greater than they would earn if they rejected sights of lower than average quality. "Since these rents are lost if the buyer decides to reject a sight and is terminated from the list of invited buyers, a wealth-maximizing buyer will not generally reject sights . . " (Kenney and Klein 1983, 506).

Important is to remember that above described practical solutions of the problems of search and inspection are a matter of an agreed upon market order (market organization), i.e., a problem of collective choice, not of the individual choice of a consistent set of consumption and production plans subject to a given market order. Thus the question is not which specific resource allocation of traders is the relative "best" but which specific market order is preferable. The usual answer of the NIE literature is that the order, which saves more on transaction costs, is preferable. Adaptability to the unforeseen or bounded rationality are hardly mentioned. In case of futures markets, ${ }^{27}$ or - more general - markets for whose products the passage of time plays an essential role (like credit markets), the problems of search and inspection are over arched by the more general problem of credible commitments - a problem we shall deal with below in our section on the organization of post contractual activities.

\footnotetext{
${ }^{27}$ Hicks $(1946, \ldots)$.
} 


\section{Contracting: Agreeing on Prices and Further Stipulations}

We shall discuss two NIE problems in this section: the problems of the formation of prices (a central issue of price theory) and of contractual stipulations (an issue of contract theory).

The mantra of neoclassical price theory is that demand and supply determine the price. It is graphically described by the Marshallian Cross. ${ }^{28}$ Vernon Smith (1962) corroborated it with his experimental study of competitive market behavior. His experiment and the praxis of auctions show that neoclassical style price formation demands the strict observation of a clearly defined set of market rules. To organize a complete market economy in this style would not only be a very costly affair, it would also demand a bureaucracy that hampered the economy's adaptability to unforeseen events ${ }^{29}$ (inclusive unforeseen ideas and technical developments). De facto, most prices are announced by one side (the producers in the case of producers' markets) and then kept constant for a while. As a consequence, prices are comparatively rigid, a phenomenon that characterizes all advanced economies. ${ }^{30}$ One transaction cost reason is the "menu costs" (the costs of changing price labels). Their size is not negligible as shown, i.a., by Levy, Bergen, Dutta, Venable (1997). Other reasons are based on the worry of price wars and irritations of customers (Blinder et al. 1998, 85), or, differently expressed, on the common desire to cultivate the price setters' business relationships with their competitors and customers.

\footnotetext{
${ }^{28}$ The illustration of the equilibrium price of a commodity by the intersection of an upwards sloping supply curve ("law of supply") and a downward sloping demand curve ("law of demand") in a system of coordinates whose vertical axis denotes the price and horizontal axis the quantity of the commodity. We are concerned here only with issues of the institutional framework of markets. For that purpose suffice, for the time being at least, the classical plausibility considerations regarding the price dependence of the quantities of demand and supply. The microeconomic foundation of these relationships and of the existence of market equilibrium is object of neoclassical microeconomics.

${ }^{29}$ Not unlike to the Lange-Lerner model of market socialism (Hayek 1945).

${ }^{30}$ However, as Carlton (1986) has shown, the degree of price rigidity differs greatly across industries. In some industries the average price does not change for periods well over one year while in other industries the price changes quite frequently.
} 
Empirical work on rigid prices exploded during the last decade (see Campbell and Eden 2007), though not with the purpose to support the NIE but to proof the non-neutrality of money and, as a consequence, the effectiveness of an active monetary policy. Rigid prices are of course changed once in a while. Traders don't change prices all the time but may try to approach equilibrium prices by a weekly or monthly trial and error process. Thus, e.g., Campbell and Eden $(2007,1)$ report, there is evidence that grocery stores "extensively experiment" with their prices. ${ }^{31}$ However, there may exist also tacit price agreements among competitors as explained by oligopoly theory, and suppliers may change their prices only according to the announcements of a one firm - the price leader (Stigler, 1952, 234).

Representatives of the New Institutional Economics such as Armen A. Alchian (1987) argue that rigid prices are part of an - between sellers and buyers - implicitly agreed upon market order. He describes the practice of posted prices as follows:

Posted prices, announced publicly and maintained until publicly revised, are prices at which the posting party will transact any amount. All parties obtain the same price; the price to a particular party could not be changed while all others were getting better prices (127).

The author gives as examples tuna and salmon fishing, "where the fishing boats are reliant on a unique buyer-processor. Similarly, a fixed price guarantee occurs in many agricultural product markets where farmers plant crops relying on a unique buyer-processor" (127). The reason is to create planning security.

Another reason for price rigidity is that, in long-term business relationships that require relationship-specific investments, "opportunistic price changes (intended to effect a hold-up) are not clearly or cheaply distinguishable from price changes to which the parties would have agreed

${ }^{31}$ Campbell and Eden $(2007,2)$ report that according to their study "Increasing the difference between an item's price and the average price for the same item at other stores substantially raises the probability of a price change. However, the probability of changing a price close to average far exceeds zero, and most price changes occur with the original price close to average. In simple menu-cost models, extreme prices arise from the erosion of a fixed nominal price by other sellers' adjustments. Therefore, they are older than average. We find that most extreme prices are relatively young (less than a month old). That is, grocers deliberately select extreme prices, which they then quickly abandon. Taken together these results suggest to us that sellers extensively experiment with their prices." (Emphasis added). 
had the demand and supply environment been mutual foreseen" (Alchian and Woodward 1987, 128).

We now come to the problem of contractual stipulations, a central issue of principal agent or adverse selection theory. Both approaches deal with problems of asymmetric information but continue to use the neoclassical assumptions of perfect rationality, perfect foresight (apart from some "asymmetric" blind spot) and zero transaction costs. Mathematically their approach is based on an ingenious form of constrained optimization with pretty far-reaching assumptions on the constraints. Thus, in case of the principal-agent approach, the principal is admittedly unable to observe what effort level his agent is supplying. But he knows perfectly well his agent's preferences and his reservation utility or the properties of the stochastic influences of nature on the result. Contracts are complete in the sense that, once concluded, they are (and can be) executed as agreed upon. It is here where Williamson's critique enters by emphasizing the problems that may arise after contract conclusion. They can be particularly bothersome if transaction specific investments play a role, which would require very detailed agreements before contract conclusion. However, under (Knightian) uncertainty it is impossible to write a complete contract that details all possible future contingencies, ${ }^{32}$ wherefore contracts are unavoidably incomplete. They contain loopholes and the lock-in of the parties (resulting from their transaction specific investments) may invite opportunistic behavior of the other side. Due to information costs (a special kind of transaction costs), the parties may be unable to verify their case to a court. Thus, governance by court ordering may have to be supplemented or even substituted by that of private ordering to effectively protect the parties against opportunism of their trade partners. ${ }^{33}$ As

\footnotetext{
${ }^{32}$ For lack of knowledge of what the future will bring, i.e., of all the stochastic variables.

${ }^{33}$ Mathematical economists such as Grossman and Hart (1986) have criticised the imprecision of TCE. They tried to develop, instead, a formal version of transaction cost economics. But their theory of incomplete contracts, as it became known, does not really deal with the central problem of TCE: ex post opportunism. Grossman and Hart
} 
one can realize, Williamson's theory of contractual stipulations (his "transaction cost theory") stretches to the Postcontractual activities we reserved for the next section.

Williamson (1983), for one, drew economists' attention to the American legal literature, in particular Macneil's concept of relational contract. It is based on long term arrangements in which past, present, and expected future personal relations among the contractual parties matter (Macneil 1974, 753). Therefore, such contracts are, to a degree, implicit, informal, and nonbinding. Self-enforcement (private ordering) becomes an important supplement of court ordering. Transactions are normally part of ongoing and long-term business associations. As such, they play an important role in modern economic life.

Often contracts are necessarily and intentionally incomplete because of mutual desires for flexible but bounded responses to uncertain future conditions that limit the scope and precision of verifiable terms. Moreover, incomplete contracts often exist deeply embedded in an ongoing relationship. The parties are not strangers; much of their interaction takes place "off the contract," mediated not by visible terms enforceable by a court, but by a particular balance of cooperation and coercion, communication and strategy. (Hadfield $1990,927)$

Sociology aside, social relations play an important role in both the legal and the economic side of the organization of markets. That is, contractual relations (Macneil 1978) develop between suppliers and their customers: Customer relationships matter. Given the specific investments on both sides, and the resulting lock-in effect, coordination by advertisements or research and development (qualitative competition) has much better properties than price adjustments. As Williamson $(1985,76)$ argues, “price adjustment proposals involve the risk that one's opposite is contriving to alter the terms within the bilateral monopoly trading gap to his advantage." 


\section{5.) Postcontractual Activities: Execution, control, and enforcement}

In the neoclassical zero transaction cost world, execution and control are unproblematic - and exchange contracts are self-enforcing. By contrast, in the NIE world with positive transaction costs, bounded rationality and incomplete foresight, arise two problems: First, the activities "execution and control" of contractual obligations require a communication mechanism that provides the information necessary to know when "enforcement" is required (cf. North 1990, 57). Second, because the activity of enforcement is often a public good of which the community benefits but the costs are born only by a small set of individuals, an order (organization) must provide incentives to carry out the enforcement when necessary - however it is done: by selfenforcement or third party enforcement (cf. North ibid.). North continues that "quite complex exchange can be realized by creating third-party enforcement via voluntary institutions that lower information costs about the other party; ultimately, however, viable impersonal exchange ..." will hardly remain self enforcing and require "institutions that can enforce agreements by the threat of coercion." (North 1990, 58) An important reason for public enforcement is that the "transaction costs of a purely voluntary system of third party enforcement in such an environment would be prohibitive. In contrast there are immense scale economies in policing and enforcing agreements by a policy that acts as a third party" - such as the state or a coalition of traders - that uses coercion to enforce agreements. (North, ibid.) However, there is a rub in it: A state "strong enough to protect property rights and enforce contracts is also strong enough to confiscate the wealth of its citizens" (Weingast 1993, 287). Hence, thriving markets require not only an appropriate system of elementary constitutional rules, “... but a secure political foundation that places strong limits on the ability of the state to confiscate wealth" (Weingast ibid.) ${ }^{34}$. What is needed is the credible commitment by the state to respect private property and individual

\footnotetext{
${ }^{34}$ The old problem of "Who will guard the guardians?"
} 
contractual obligations - in effect, a self-enforcing order (constitution) of the state itself. Even though this is an old and well-discussed insight of the science of the state, many of the economists "doctoring the ailing economies of central and eastern Europe" (North 1993. 12) believed that the necessary institutional framework of a free market "will be the automatic outcome of getting the prices right through elimination of price and exchange controls."(ibid.).

To summarize so far: Under conditions of the NIE, the three elementary market activities of execution, control, and enforcement require the provision of two explicitly or implicitly agreed upon mechanisms: First, a communication mechanism that informs marketers when "enforcement" is required; second, an enforcement mechanism- that is respected by the parties of exchange. The two mechanisms themselves need to be based on a set of a higher order rules (a constitution) that regulate their respective execution, control, and enforcement, which again may be explicitly stated or implicitly agreed upon (an explicit or implicit order or in the terminology of Hayek 1973, 37: a "made" or "grown" [spontaneous] order).) In other word, not only the execution, control, and enforcement of contractual obligations (a private good) - given a market order - but also the execution, control, and enforcement of the market order itself (a public good) is of interest. Coase's complaint is aimed at the latter: the explanation of the contents of the market order (of the institutional framework or the organization of the market) and its enforcement mechanism. This leads unavoidably to a line of institutional economics dating back to Hume (1739/40), Menger (1883) and Hayek (1948). Schotter (1981) translated it into the language of game theory, in particular the theory of repeated prisoner dilemma games, to explain the possibility of persistent, self-enforcing institutional arrangements. Economists like Telser (1980), Greif (1998, 2005), Aoki (2001) or Dixit (2004) use it to

\footnotetext{
"demonstrate formally how even the most selfish individuals will often find it in their own enlightened selfinterest to cooperate with their neighbours in a long-term relationship." (Binmore 1992, 21)
} 
In this approach, to be sure, information or transaction costs play a role but are no essential explanatory element; furthermore, game theory assumes perfect rationality and requires very detailed information about what can happen. Insofar it is inconsistent with the assumptions of transaction cost economics. We dubbed this branch of Institutional Economics the institution-asan-equilibrium-of-game approach (Furubotn and Richter 2005, 8). This approach can be used to explain both, self enforcing exchange agreements between individual buyers and sellers (private choice problem) and self enforcing agreements between a multiplicity of marketers on a market order or organization (collective choice problems). The latter comprises the use of money in market exchange, the definition and guarantee of property and contract rights, and other "givens" of neoclassical economics.

According to this approach an institution is defined as a salient Nash equilibrium ${ }^{35}$ of a recurrent "supergame" about the way a given "underlying game" (e.g., a prisoner's dilemma game) is repeatedly played. It is self-enforcing in the sense that it is in each actors' own interest not to deviate from his decision ("not to stray from the straight and narrow"). The term "force" is misleading since no brachial "force" is applied only the "force" of each actors' own interest.

Note, the result of Nash equilibrium needs neither to be the best possible payoff for all actors. In the opposite, it may be a state detested by all participants who find themselves in a strategic deadlock. Furher, a Nash equilibrium needs it to be the result of some "spontaneous" action (an "invisible hand" mechanism). It may well be the result of a "made" order (e.g., by law makers). However, since in the world of the NIE there is no legal, administrative or judicial perfection there will be also no perfectly "made" order Thus, formal institutional arrangements such as constitutions, laws, exchange contracts etc. remain unavoidably incomplete and need completion by informal arrangements (orders) such as "community norms based on intense social

\footnotetext{
${ }^{35}$ The state of a game in which each player makes his best decision taking into account the other players decisions.
} 
interaction" (Aoki, 2001, xvii) or "private orderings" between traders (Williamson 1983, 520). Even in countries with functional legal systems, private ordering complements or even substitutes public ordering. Not amazingly, the study of private ordering became "a lively research subject that spans several traditional disciplines - economics, law, politics, sociology, anthropology. It merits recognition as a field in its own right, or perhaps as a subfield of the New Institutional or Organizational Theory.” (Dixit 2004, 149).

One of the basic assumptions of private ordering in the form of self-enforcing mechanisms is that the misbehavior of players is public information. However, due to transaction costs, real world players are in general incompletely informed. Even though transaction costs play no [essential] role in game theory, game theoretic explanations of self-enforcement mechanisms are applied to answer real world situations characterized by costly information. Such models are therefore assumed to contain special private or small-scale public institutions that provide low cost information about each player's behavioral history and coordinate community responses. The development of such institutions is the object of divers historic studies by scholars such as Milgrom, North and Weingast (1989), Greif $(1989,1993,2006)$ and Greif, Milgrom and Weingast (1994). However, from a certain point on transaction costs of such private (or small public) systems of third party enforcement would become prohibitive (North 1990,58) and will result finally in the establishment of a territorial state - in spite of the problems of its control. We'll relate in this paper briefly only on three articles - two historic contributions by Greif (1993) and, Greif, Milgrom and Weingast (1994) plus one on modern times by Baron (2002).

The two historic papers describe an early and a more intermediate stage on the road from personal to impersonal exchange - both characterized by the separation between the quid and the quo over time and space. The paper on modern times describes one of todays most successful dot-com ventures: the reputation mechanism of eBay's online market. 
The first paper by Greif (1993) deals with the problem of trust between a merchant and his travelling agent using the example of the organization of a coalition of Jewish traders, the Maghribi, who pursued complex, long-distance trade in the Mediterranean during the eleventh century. The Maghribi had organized an informal principal-agent relationship——with the traders being the principals and their employed "overseas agents" being the agents. The latter accompanied the sea transport of the goods, searched for buyers, negotiated and concluded purchasing contracts, monitored the transfer of the goods, and secured payments. Complete contingent contracts between principals and agents were impossible because of lack of foresight. Also impossible was a direct monitoring of the agents by the principals. Similarly, court ordering against fraudulent agents was not feasible. Despite these difficult conditions, the Maghribi merchants were still able to help themselves by establishing the following agreement. The agents were, or became, members of an economic institution, the group of traders of the Maghribi. They earned premiums for good behavior. But, if any agent deceived his principal just once, he got no more assignments for the rest of his life from the merchants of the Maghribi group. If a fraudulent agent tried to become a principal (a merchant) himself, his Maghribi agent was free to deceive him. No Maghribi tradesmen or merchants would punish him in the usual manner. Thus, he would soon be driven out of business. Insofar, “...the Maghribi traders established a relationship between past conduct and future economic rewards. As a result, agents resisted the short-term gains attainable through deception ... " (Greif 1989, 881).

The second paper by Greif, Milgrom and Weingast (1994) interprets merchant guilds in the light of a repeated-game model to conclude that guilds emerged to allow rulers of trading centers to credibly commit themselves to the security of the person and property of alien merchants. They centralized information about rulers' behaviour and disputes among merchants, and were able to apply sanctions against breach of promises by rulers (city governments) that required effective 
collective actions. In effect, guilds provided merchants with the leadership and the information transmission mechanism required for coordinated action. They decided when to impose a trade embargo and when to cancel it. (p. 755) Members could also obtain information from guilds about disputes between their members or other traders. Modelling city - trader relationships as equilibria of repeated games is impossible because of the asymmetry of power (size) between city and foreign traders. Also the interposition of a merchant guild, which organizes communication and coordination between traders, does not necessarily lead to reputation equilibria because individual traders have no incentive to participate in the boycott of a city. To be effective, merchant guilds (like labor unions) have to be strong enough to force members to do so rather than to serve their individual interest (771). The authors do not deny that merchant guilds were cartels but maintain that they originally served as countervailing powers against rulers of trading centers (cities) and thus facilitated trade expansion. In the course of time, when larger political units emerged and took over the functions of merchant guilds, merchant guilds did not necessarily disappear but were transformed into monopolistic organizations that may have hindered the expansion of trade. (773) - The institution of the merchant guild was so to speak complemented by the institution of the "community responsibility system" as described by Greif (2006). It was a further step into the direction of modern impersonal exchange.

One of the most extreme cases of modern impersonal exchange represents the online auction market organized by eBay. Baron (2002) gives a detailed description of it. Traders are anonymous and remote; buyers cannot examine the items before bidding and have to pay in advance for items they had not inspected. Sellers have little recourse if a winning bidder refuses to pay (Baron 2002, 254). Still, trade flourishes and eBay became one of the true dot-com successes. Its achievement is based on trust among members of the "eBay community of traders," which represents eBay's principal asset; “eBay’s strategic focus is to support and expand this 
community." For that purpose eBay established and attends to a multilateral online reputation mechanism based on [published] feedback provided by the transacting parties $(2002,246)$. This mechanism generated incentives similar to those in a long-term personal relationship between buyer and seller. Of course, a community based on trust was vulnerable to (outright) fraud. But fraud remained rare and can be covered by an insurance against fraud (2002, 272). Baron concludes:

\footnotetext{
"The internet allowed an online reputation mechanism to support trust among anonymous traders, most of whom would not have repeated bilateral exchange. The reputation mechanism was multilateral and based on feedback provided by the parties to a transaction. This mechanism was the heart of eBay's strategy of building a community and sharing in the value created for its members." (Baron 2002, 272)
}

So much on our three examples; for a systematic review of economic historic papers on private ordering that are largely based on the problem of prisoner-dilemma games see McMillan and Woodruff (2000). They emphasize two ways to counter the self-defeating incentives of PDgames: The law and repeated PD games with the possible threat of retaliation. "If the legal system functioned perfectly, contracts would never need to be self-enforcing. The advantage of private ordering is that the market participants are mostly better informed than judges. “ Important as private ordering may be - in a modern society it could not replace public ordering.

Before continuing we wish to allude to the fact that the institutional details of above six basic activities of trade (exchange) are subject matter of civil law. Consequently, typical NIE reasoning may be also illustrated by interpreting above presented NIE literature on the basis of legal regulations like facets of property right law and contract law (for some examples cf. Furubotn and Richter, 2005, ch. 3 and 4).

\footnotetext{
36 There is also an internet market for "peer-to-peer lending" In the USA see, e.g., Lending Club "http://www.lendingclub.com/home.action oder Zopa http://uk.zopa.com/ZopaWeb/, oder Loanio: http://www.netbanker.com/2007/06/new person to person_lender loanio readies for launch.html (NYT, 16. Okt. 2008, B1, 10). In Germany, e.g., Auxmoney: http://www.auxmoney.com/start/howto.php
} 


\section{6.) Final Remarks}

As we have seen, the market is not just "supply and demand determines the price." To function properly, it demands a set of rules that regulate not only the price mechanism, but also all other basic functions of trade like search, inspection, contracting, execution, control, and enforcement. Independent of whether these rules evolved spontaneously or were made by identifiable people, they must be well designed and well implemented. As the present sub prime mortgage crisis illustrates: the quality and execution of trading rules is vital for the functioning of the market itself - of the market as an organization -, which is by no means a marginal problem.

Though there exists no systematic new institutional economic theory of the "market itself," we are able to draw a couple of general institutional economic conclusions, viz.,

- Purely spontaneous markets, such as street markets, are not typical. In general markets

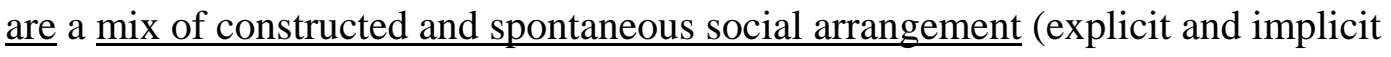
social orders) to facilitate repeated exchange among a plurality of parties at low costs of using the market ("transaction costs").

- Markets, as any human organization, are mechanisms that fulfill certain elementary functions. The elementary functions of markets may be interpreted as the activities of $\underline{\text { search, inspection, contracting, execution, and control. }}$

- To economize on the costs of using the market in their wider sense (incl. transportation and information costs), traders have to agree on a set of basic properties of markets, among them (1) where and when markets are to be held, (2) which commodities shall be traded and by whom, (3) what units of measurements are to be used, (4) which units of account and means of payments shall be applied, and (5) who determines and guarantees the basic rules of trade (the market order and its application). 
- $\quad$ These basic market properties apply everywhere and anytime. Properties (1) and (2) are largely decided on by the marketers themselves (i.e. by private individuals) while in modern society properties (3) to (5) are determined and guaranteed by the State (i.e., by the public).

- Our hypothesis is that a market may be conceived as a public good that may be privately or publicly supplied and administered.

Different from the teachings of neoclassical micro economists or German Ordo economists, ${ }^{37}$ new institutional economists reject the use of "perfect markets" as benchmark of the economic quality of markets (their "efficiency"). Instead, they try to give reasons for possible economic advantages of market "imperfections" such as contextual uninformative advertisements (search: Nelson), bundling (inspection: Barzel, Kenney and Klein), social networking (search: Granovetter), price rigidity (search: Alchian and Woodward), non-standard contracts (self enforcement: Williamson), or private ordering (Williamson, Greif) - by stressing also the necessity of court ordering for modern market economies (North, Weingast). Still, fascinating remains the up to now unanswered question of how viable market orders (a special case of social structures) come about - a question largely directed to economic historians and sociologists.

\footnotetext{
${ }^{37}$ Like Eucken (1952).
} 


\section{References}

Abolafia, M.Y. (1984),"'Structural Anarchy: Formal Organization in the Commodity Futures Markets", in: Adler and Adler (1984), 129 - 149.

Alchian, A.A. und Woodward, S. (1987), "Reflections on the Theory of the Firm", Journal of Institutional and Theoretical Economics, 143, 110-137.

Aoki, M. (2001), Toward a Comparative Institutional Analysis, Cambridge, MA

Arrow, K. J. 1969. "The Organization of Economic Activity: Issues Pertinent to the Choice of Market versus Non-Market Allocation." In The Analysis and Evaluation of Public Expenditures: The PBB-System, Joint Economic Committee, 91st Cong., 1st sess., vol. 1. Washington, D.C.: Government Printing Office.

Barharad, E. and Eden, B. (2004), "Price Rigidity and Price Dispersion: Evidence from Micro Data," Review of Economic Dynamics, 7, 613-641.

Baron, D. P. (2002), "Private Ordering on the Internet: The eBay Community of Traders," Business and Politics, 4, 245 - 274.

Barzel, Y. (1982), "Measurement Cost and the Organization of Markets", Journal of Law and Economics, 25, 27-48.

Binmore, K. 1992. Fun and Games: A Text on Game Theory. Lexington, Mass.: D. C. Heath.

Blinder, A.S.; Canetti, E.R.D.; Lebow, D.E.; Rudd, J. B. (1998), Asking About Prices. A new Approach to Understanding Price Stickiness, New York: Russell Sage Foundation.

Burt, R. S. 1983. Corporate Profits and Cooptation: Networks of Market Constraints and Directorate Ties in the American Economy. New York: Academic Press.

Campbell, J.R. and B. Eden (2005), Rigid Prices: Evidence from U.S. Scanner Data, Federal Reserve Bank of Chicago, Working Paper Series. http://www.chicagofed.org/publications/workingpapers/wp2005_08.pdf

Carlton, D. W. 1986. "The Rigidity of Prices.” American Economic Review 76:637-58.

Coase, R.H (1937), "The Nature of the Firm", Economica, 4, 386-405.

Coase, R.H. (1974), "The Lighthouse in Economics," Journal of Law and Economics, 17, 357 376.

Coase, R.H. (1988), The Firm, the Market, and the Law, Chicago and London: The University of Chicago Press.

Coleman, J.S. (1984), "Introducing Social Structure into Economic Analysis", American Economic Review, Papers and Proceedings, 74, 84 - 88.

Demsetz, H. (1969), "Information and Efficiency: Another Viewpoint", Journal of Law and Economics, 12, 1-22

Dimand, R. W. (2008), "monetary economics, history of", The New Palgrave Dictionary of 
Economics, Second Edition, St. N. Durlauf and L. E. Blume (eds), Palgrave Macmillan.

Dixit, A. K. (2004), Lawlessness and Economics. Alternative Modes of Governance, Princeton, N.J.: Princeton University Press.

Egbert, H. (2007), "The Culture of a Market: A Case of Open-air Horse Markets," Journal of Institutional and Theoretical Economics, 163, 493 - 502.

Eucken, W. (1952/1975), Grundsätze der Wirtschaftspolitik, 5. ed., Tübingen: J.C.B. Mohr (Paul Siebeck).

Furubotn, E.G. and Richter, R. (2005), Institutions and Economic Theory. The Contribution of the New Institutional Economics, $2^{\text {nd }}$ revised and extended edition, [1 ${ }^{\text {st }}$ ed. 1997], Ann Arbor, MI: University of Michigan Press.

Granovetter, M. (1974/1995), Getting A Job. A Study of Contacts and Careers, Chicago, $2^{\text {nd }}$ edition 1995.

Greif, A. (1989), „Reputation and Coalitions in Medieval Trade: Evidence on the Maghribi Traders“, Journal of Economic History, 49, 857-882.

Greif, A. (1993), „Contract Enforceability and Economic Institutions in Early Trade: The Maghribi Tranders' Coalition", American Economic Review, 83, 525-548.

Greif, A. (1998), "Self-Enforcing Political Systems and Economic Growth: Late Medieval Genoa", in R.H. Bates, A. Greif et. al. (1998, 23-63).

Greif A. (2005), "Institutions, Markets, and Games," in: V. Nee and R. Swedberg (eds.), The Economic Sociology of Capitalism, Princeton: Princeton University Press.

Greif, A. (2006), Institutions and the Path to the Modern Economy: Lessons from Medieval Trade (Political Economy of Institutions and Decisions), Cambridge: Cambridge University Press.

Greif, A., Milgrom, P. und Weingast, B.R. (1994), "Coordination, Commitment, and Enforcement: The Case of the Merchant Guild", Journal of Political Economy, 102, 745-776.

Grossman, S. J., and O. D. Hart. 1986. "The Costs and Benefits of Ownership: A Theory of Vertical and Lateral Integration." Journal of Political Economy 94:691-719.

Hadfield, G. K. 1990. "Problematic Relations: Franchising and the Law of Incomplete Contracts." Stanford Law Review 42:927-92.

Hamilton, G. G., and R. C. Feenstra. 1995. "Varieties of Hierarchies and Markets: An Introduction." Industrial and Corporate Change 4:51-91.

Hart, O. and Holmström, B.R. (1987), "The Theory of Contracts," pp. 77 - 155 in: T. Bewley (ed.). Advances in Economic Theory, Cambridge: Cambridge University Press-

Hart, O. D. 1995. Firms, Contracts, and Financial Structure. Oxford: Clarendon.

Hayek, F.A. (1945), "The Use of Knowledge in Society", American Economic Review, 35, 519-530.

Hayek, F.A. (1948) Individualism and Economic Order, Chicago: University of Chicago Press.

Hayek, F.A. (1967), Studies in Philosophy, Politics, and Economics, Chicago: University of Chicago Press. 
Hayek, F.A. (1973), Law, Legislation, and Liberty: A New Statement of the Liberal Principles of Justice and Economy, Vol. 1, Chicago: University of Chicago Press.

Hicks, J.R. (1946), Value and Capital. An Inquiry into some Fundamental Principles of Economic Theory, $2^{\text {nd }}$ ed., Oxford: Clarendon.

Hume, D. [1739-40] 1969. A Treatise of Human Nature. Edited by E. C. Mossner. London: Penguin.

Kahneman, D. 1994. "New Challenges to the Rationality Assumption." Journal of Institutional and Theoretical Economics 150:18-36.

Karazman-Morawetz, I. and Pilgram, A. (1993), “Ostgrenzöffnung als Gelegenheit: irreguläres Erwerbshandeln und seine Kontrolle," pp. 147-168 in: A. Pilgram (ed.), Grenzöffnung, Migration und Kriminalität. Jahrbuch für Rechts- und Kriminalsoziologie 1993, BadenBaden: Nomos.

Kenney, R.W. und Klein, B. (1983), "The Economics of Block Booking", Journal of Law and Economics, 26, 497-540.

Lancaster, K. 1969. Introduction to Modern Microeconomics. Chicago: Rand McNally.

Levy, D., M. Bergen, S. Dutta, and R. Venable. 1997. "The Magnitude of Menu Costs: Direct Evidence from Large U.S. Supermarket Chains.” Quarterly Journal of Economics 112:791825.

Macneil, I.R. (1974), "The Many Futures of Contracts", Southern California Law Review, 47, 691-816.

Macneil, I.R. (1978), "Contracts: Adjustment of Long-term Economic Relations Under Classical, Neoclassical, and Relational Contract Law", Northwestern University Law Review, 72, 854-905.

McMillan, J. and Woodruff, C. (2001), "Private Order Under Dysfunctional Public Order," Michigan Law Review, 98, 2421 - 2458.

Menger, C. (1883), Untersuchungen über die Methode der Socialwissenschaften und der Politischen Oekonomie insbesondere, Leipzig (Neuauflage Tübingen 1969).

Milgrom, P. R., North, D. C. and Weingast, B. R. (1990?), “The Role of Institutions in the Revival of Trade: The Law Merchant, Private Judges, and the Champagne Fairs, Economics \& Politics, 2, $1-23$.

North, D.C. (1990), „A Transaction Cost Theory of Politics,” Journal of Theoretical Politics, 2 , $355-367$.

Schelling, T. C. 1960. The Strategy of Conflict. Cambridge: Harvard University Press.

Schmidtchen, D. (1984), “German 'Ordnungspolitik' as Institutional Choice," Zeitschrift für die gesamte Staatswissenschaft/Journal of Institutional and Theoretical Economics, 140, 54 - 70.

Schotter, A. (1981), The Economic Theory of Social Institutions, Cambridge, MA.

Selten, R. 1990. “Bounded Rationality.” Journal of Institutional and Theoretical Economics 146:649-58.

Sik, E. and Wallace, C. (1999), "The Development of Open-air Markets in East-Central Europe," International Journal of Urban and Regional Research 
Simon, H. A. (1957), Models of Man. New York: Wiley.

Smith, V. (1962), "An Experimental Study of Competitive Market Behavior," Journal of Political Economy, 70, 111 - 137.

Solow, R.M. (1956), “A Contribution to the Theory of Economic Growth," Quarterly Journal of Economics, 70, 65 - 94.

Spence, A. M. 1974. Market Signaling: Information Transfer in Hiring and Related Screening Processes. Cambridge: Harvard University Press.

Spence, A. M. 1976. "Informational Aspects of Market Structure: An Introduction.” Quarterly Journal of Economics 90:591-97.

Stackelberg, H. von (1948), Grundlagen der theoretischen Volkswirtschaftslehre, Bern: A. Francke Verlag.

Stigler, G.J. (1952), The Theory of Price, rev. ed., New York: Macmillan Co.

Stigler, G.J. (1961), "The Economics of Information", Journal of Political Economy, 69, 213-225.

Stigler, G. J. (1968), Art. „Competition“ in: International Encyclopedia of Social Sciences, 3 New York: Macmillan, 181 - 182.

Stützel, W., 1959, "Liquidität" in E. v. Beckerath et.al., eds., Handwörterbuch der Sozialwissenschaften, Vol. 6, Stuttgart, 622-629.

Telser, L.G. (1980), "A Theory of Self-Enforcing Agreements", Journal of Business, 53, 27-44.

Thünen, J.H. von (1826), Der Isolierte Staat in Beziehung auf Landwirthschaft und Nationalökonomie, oder Untersuchungen über den Einfluß, den die Getreidepreise, der Reichthum des Bodens und die Abgaben auf den Ackerbau ausüben, Hamburg: Pertes.

Weingast, B. R. 1993. "Constitutions as Governance Structures: The Political Foundations of Secure Markets." Journal of Institutional and Theoretical Economics 149:286-311.

Weingast, B. R. (1995), “The Economic Role of Political Institutions: Market Preserving Federalism and Economic Development." Journal of Law, Economics, and Organization 11:1-31.

Williamson, O.E. (1983), "Credible Commitments: Using Hostages to Support Exchange", American Economic Review, 73, 519-540.

Williamson, O.E. (1985), The Economic Institutions of Capitalism, New York et al.: Free Press. 